\title{
The Application Research on Interactive Teaching Mode in the Course of Transportation and Distribution Management
}

\author{
Liyun QI, Jiaqi LUO, Tengfei LI \\ Faculty of Management and Economics, Dalian University of Technology, Dalian \\ Dalian Maritime University, Liaoning, Dalian
}

ABSTRACT: Based on the practice teaching, fully integrate with the experience in the process of teaching, the students' feedback about the teaching mode as well, also with the help from analysis and research, we studied the application of interactive teaching in "transportation and distribution management" course, further enriched the teaching content, emphasizing "the three a model of interaction between teacher and student, among students and that between school and enterprise". Meanwhile, according to the problem existed in the "transportation and distribution management" course, some specific interactive measures was put forward, such as, the current database, situational teaching and promote the interaction between school and enterprise.

KEYWORD: Interactive Teaching Mode; Transportation and Distribution Management; Current Database; Situational Teaching

\section{INTRODUCTION}

The course of transportation and distribution management is the key stone course for logistics management major. It is a transforming course for student to learn from pure theoretical knowledge to actual combat management technology. It is also a bridge between theory and practice for students[1]. Logistics management is a strong professional practical course, so in the transportation and distribution management course, teaching must be put on the important position. In order to achieve talents training goal, we need to let the students learn from doing and to do in learning. Interactive teaching mode meets the needs of talents training at the current stage and its effectiveness is agreed by a lot of educators and education agencies. However, restricted by various factors, this teaching mode has not been widely spread in our country, the interaction is a more of a "subject", especially in the aspect of students to interact with enterprises. Universities should support the application of interactive teaching mode within the scope of their power. In the future, the widespread application of this teaching mode will be the inevitable.

\section{ANALYSIS OF PROBLEMS IN THE COURSE OF TRANSPORTATION AND DISTRIBUTION MANAGEMENT}

At present, most universities open the course of transportation and distribution management or similar course for logistics management major. Common phenomenon is that the teaching of the course is given priority to theory, not practice and even with only theoretical knowledge. The single teaching mode severely compressed the proportion of practice teaching, beneficial to promote students' practical ability training mechanism has not been able to form effective interaction[2].

\subsection{The low level of teachers' comprehensive quality.}

As a crucial member of the process of teaching, teachers and their quality play an important role to the teaching effect. Transportation and distribution management course is a practice course and the teacher of it needs to have some practical experience to some extent. And at present, teachers who are skilled on both theoretical knowledge and practical experience are scared in China. Pure theoretical teaching is not only hard to understand, but also can make students feel boring, and then to produce weariness. If only have the practical teaching, students can't grab the theoretical knowledge system and will make students lost the foundation of 
innovation. Therefore, it is very urgent to train teachers. Organizing professional teachers to work in enterprises will enhance their consciousness and the ability of theory with practice.

\subsection{Not enough emphasis on practice teaching}

The widespread phenomenon exists in the related teaching process is weight more on theory and weight less on practice. This is mainly manifested in the following aspects[3]: first of all, the fewer the number of hours of practice teaching. Many universities are aware of the arrangement of the necessity of practice teaching; however, the time they allocate to practice teaching is not much. The arrangement cannot match with the students' needs. Secondly, teaching practice becomes a mere formality. On the one hand, as many universities are trapped in the limitation of resources, practice teaching is discounted and often be shout out loudly, but with no action. On the other hand, with the consideration of protecting confidential or other interests, most enterprise is not willing to cooperate with universities in teaching, even if the universities has arranged for related internship, students are also difficult to really get into the enterprise. They can only see some formal content. What's more, some universities only arrange hours for practice teaching, however, they did not arrange the resources to implement it, practice teaching is just a facade.

\subsection{Capital investment on practice teaching is seldom}

In recent years, with the rapid increase of numbers of recruiting logistics management major students, the number of teaching resources per capita has a sharp decline. In the aspect of hardware, only a few universities can set up logistics management professional laboratory. In the minority, more than half of them belong to small to medium size. In addition, the stable business practice bases established by universities are in the minority. In terms of teachers, people who have skill on both theory and practice are hard to find, many universities tend to be retained by the graduates majoring in economic management and they are serious lack of practical experience[4]. All of these become the bottleneck which restricts the development of practice teaching. The essence of interactive teaching mode is "interaction". The range contains not only the interaction between teachers and students, the interaction between students, but more interaction between students and interaction, namely the real practice[5]. Only test in practice can let students learn a deeper understanding to theoretical knowledge and can better guide the practice of later. Through this learning process, students can meet the hiring requirements of the enterprise.

\section{THE CONSTRUCTION OF INTERACTIVE TEACHING MODE}

The interactive teaching mode advocated by this research institute not only includes interaction between teachers and students, interactions among students, but interaction between students and enterprise as well. In this way, students can contact their own learning to practice and learn theory from it. Through the learning from both theory and practice, students can improve their understanding of this course in order to achieve the teaching results. Interactive teaching breaks through the bondage of the traditional teaching mode and changes the traditional roles of teachers and students in the class. In this kind of teaching model, students have more autonomy. Not being raised like Peking duck, it is helpful to improve students' enthusiasm, innovative thinking and innovative spirit. This study will base on "Current news teaching" + "Situational teaching" + "Enterprise practice" mode of interactive teaching and strengthen the link of course of transportation and distribution management between theory and practice for bachelor students who are major on logistics. This research is proposed to focus on the following three aspects.

\subsection{Develop and update the teaching "current news library"}

This research takes the theory of transportation and distribution management as the main line and summaries China's logistics enterprises' practice on transportation and distribution management in recent years. At the same time it also focuses on selected social activities in the fields of production and circulation in the actual problem and the closely related current affairs for teaching. Raised up questions from teaching content and divides students into group which will let them discuss and report what they have found. This will serve as a bridge between knowledge transferring and application. On the basis of knowledge accumulating, current news library can be developed and updated. Specific research contents are as follows:

(1) Design and establish the current news library. The so-called current news library is the network, newspapers, magazines and other channels to collect real events which has not been processing and carve. At same time, not only to extract for an event, but also reflect how the whole event happened. With discussion study method added, students can learn the advantage and disadvantage of practice method and which in turn let the students have a deeper understanding of related knowledge. It can also help 
the students to furnish their own database of knowledge through learning from others point of view. In order to cope with teaching with current news, it is urgent to establish a comprehensive current news library. The establishing of current news library is a basic and multifarious engineering which needs a lot of work on searching. During this process, students can be involved. This can diversify the sources of current news library and also help the students have a more intuitive understanding of building current news library and let them to fully understand the theory they learn from class. In addition, there is formal format of events recording in current news library.

(2) To revise and enrich the current news library's content and decision making based on simulation and write out the instruction manual. The easy learned instruction manual can help the students to search the relevant events in the current news library whenever they need. Therefore, teachers will not need to teach student hand in hand. This is useful for enlarging the current news library's range and meanwhile it will cultivate the students' initiative and self learning ability.

(3) The development of cases for teaching according to different requirements. For example, based on the characteristics of transportation, we use all kinds of typical things to clarify the essential feature of the mode of transportation in order to infer the common characteristics of things from single event and then grasp the objective trend of the development. In order to develop the real examples of "advantages and disadvantages of transportation", it can summaries "Haier logistics process reengineering" base on modern logistic distribution method; To summaries "Suning's logistics system" base on E-commerce and distribution; To summaries "Zhonghai Group's construction of logistic center" base on logistic distribution center. With the hot issues of modern logistics, comprehensive utilization of text, video and other multimedia form around, develop and the modern logistics and distribution.

(4) Use current news library in the next school years and collect the feedbacks from students and to adjust and improve the quality of current news library. The current news library needs to be updated periodically. With the development of the society, every industry is upgrading. Facing the new questions and situations, we need to have new methods and ideas to match with them. Old ideas cannot solve the new problems. With the fully upgraded current news library, students' ideas can be motivated and they can be more familiar with the new logistics. Therefore, it is necessary to update the contents in the current news library.

(5) To sum up the current news library for transportation and distribution management and select the relevant events from it to write out cases for transportation and distribution management. We need to encourage our students to join the match of best cases selection competition and strengthen the promotion and application of the above results. Write out the excellent cases and publish them. On the one hand, it will solve the problems of lack of good cases. On the other hand, it can furnish the teaching of course of transportation and distribution management.

\subsection{The introduction of situational teaching model}

With the application of simulation software of transportation and distribution management, it can create virtual transport and distribution enterprise environment, and provide students with the social reality of the logistics system simulation scenarios. In the undergraduate course of situational teaching model, following aspects also need to pay attention to.

(1) According to the characteristics of the course of transportation and distribution management and matching with hardware of the universities, suitable simulation software can be selected. Teaching simulation software can build situation for knowledge of transportation and distribution management and it can inspire students' interest in learning, arouse the enthusiasm of the students thinking, and improve students' ability to understand, digest and flexible use of knowledge. Simulation software can set the task to guide students to explore and learn independently, and will promote students take the initiative to acquire knowledge, screening of useful information, and grasp the ability of problem solving. In order to explore effective teaching methods, we need to fully understand the operation experience and the characteristics of simulation software and set the teaching plan. For examples, completes the data collection and analysis in advance, discuss the decision making and record the notes in class, completes the summary and improvement scheme after class. Also, students can exchange the experience through discussion.

(3) Pay attention to the interaction between teachers and students during the situational teaching. Guiding by teachers, students can form teams and finish the simulation projects under match. This is a innovative and efficiency learning method and can let the students to have fun which in turn to promote their comprehensive quality.

(4) Establish suitable performance evaluation system. This can reflect student's team working sprit and personal characteristics and improve their practical ability. Both hardware and software to the student's comprehensive considerations has a great role in promoting students' comprehensive quality has a great role in promoting.

(5) Guiding students to join matches of logistics innovation and students' entrepreneurial project. Situational teaching should be ahead of students' 
internship and the loss in the simulation is less than the loss in reality. In addition, Situational teaching method is the make up for practical teaching method. Most universities constrained by the resource cannot have enough practical teaching. Under this situation, situational teaching method is the first option.

\subsection{To build the practical projects related to the interaction between students and enterprises}

With the goal of training practical talents, we need to let the students to join the management of logistics companies and strengthen their understanding of enterprises logistics activities. The following questions need to be aware of.

(1) Emphasis the training for the students' ability of practical and clear up the projects' objective, content, evaluation system and security system. Enterprise practical projects are system engineering and a good application system can satisfy the teaching and achieve a good teaching results.

(2) Enlarge the construction of enterprise practical bases and cooperate with enterprise like partnership. The constructions of enterprise practical bases are very important and mutual trust, mutual benefit and mutual help need to be set up. When the enterprises know the benefit of building enterprise practical bases, they will try their best to invest into the projects and fulfill the goal of students' practical lessons.

(3) Let students to search the information of the enterprises on internet and learn the current situation of the enterprise's logistic management. And then, let the students to think about the answers for the problems in the process of transportation and distribution management. To sum up, students need to prepare questions before they visit the enterprise and this can maximize the benefits of interaction.

(4) Study with enterprise logistics employees and let them introduce the current questions face by the enterprise. These employees work in the real situation and have much experience and they can enlarge students' sight-seeing.

(5) Through visiting the enterprise and let the students to think about the questions faced by logistic enterprise can help them to give out relevant question and propose a good solution. During the teaching process of the writer, students are arranged to visit Dalian container terminal mail company. Logistic manager from Dalian shipbuilding industry group of Marine engineering co., LTD and project manager from Dalian Airport Distribution Center are invited to have a face to face communication with the students. In the future, more enterprise will be invited and more contacts will be built up. In a word, it is good to have interaction with enterprise during the teaching process. The rate of interaction with teachers is increasing and students' term work sprit are enhancing. At the same time, combined theory with practical, students will not be bored with class and this method has been acquiring recognition from both students and enterprise. Students forms reports after enterprise visiting and it contains deeper analysis of each enterprise distribution system with advantage and disadvantage .in China and aboard. To be happy, students also give their own questions found and give their own solution. This way of teaching can inspire the students learning interests. Everyone thinks the visiting to enterprise is beneficial and give feedback on more opportunities on visiting in future. The application of practical teaching mode is the makeup and perfection for traditional teaching mode. This means that China's teaching method is changing. Practical teaching brings a new feeling for students and this reflects the old saying "Travelling is more important than reading". Without the key of practical, the real doors of theory cannot be open. To train logistics talents with practical experience, practical teaching mode must be put into application.

\section{CONCLUSION}

Facing the fasting changing society and internationalization, successful talent training is the best option to catch up with opportunities. With the rapid development of logistic management, more and more comprehensive talents are needed. The Universities must take this responsibility to fulfill the society's workload demands. Interactive teaching mode put the students' practical ability on the first place and it does not give up the theory teaching. This mode is a good way of training talents with both theory and practical skills. Enlarging the support power for interactive teaching and encouraging teachers to improve it is the basic need of the society and it is also the key stone for the development of our nation.

\section{REFERENCES}

[1] Wang Zhili. The Application of Interactive Mode in the Teaching of Logistics Management. Journal of Guangzhou Maritime College, 2009, 17(2): 56-58

[2] Jiang Xusheng. On the Practice Teaching Reform of Logistics Management in Vocational College-Based on Combining Work and Learning. Journal of Chuzhou University, 2012, 14(1): 123-125

[3] Liu Bin. Analysis on the Practice Teaching of Logistics Management Specialty and Its System Establishment. Logistics Engineering and Management, 2009, 178(4): 143145

[4] Wu Yisheng. Research on the Innovation Cultivation Mode Constructing for Application-oriented Logistics Management Talents. Logistics Sci-Tech, 2009, 11: 94-96

[5] Zhao Xiaofei. On a Practice Teaching System to Cultivate Undergraduate Logistics personnel of Application Type. Journal of Chongqing University of Arts and Sciences, 2012, 31(3): 92-94. 